\title{
THE BRAZILIAN WOMAN: FROM THE COLONIAL PHOTOGRAPHY TO CONTEMPORARY PORTUgUeSE PHOTOGRAPHY
}

\author{
Lorena Travassos
}

\begin{abstract}
This study aims to carry out an initial analysis of how the Brazilian woman image is shaped by a discourse that is historically constructed and reinforced by colonial photography. This visuality has endured through the ages and represents a form of contemporary colonialism, as it is characterized by an identity reductionism disguised as a global ideology. The possibility of paradox prevalence in these speeches is analyzed through a critical view of the work of André Cepeda and Miguel Valle de Figueiredo, Portuguese photographers who has produced photography artwork about the Brazilian woman. In these images, the construction of a visual concept of Brazilian women revealed underlying statements supported by their perceptions and experiences, as well as in generalized beliefs. Thus, it was concluded that the understanding of the image of Brazilian women as portrayed by those photographers shows itself covered of brand new colonizing processes in which the Brazilian woman's image is linked with a sense of an available and sensual body, imbued with the concept of a colonial body that still persists in contemporary imagery.
\end{abstract}

KEYWORDS

Visuality; photography; colonialism; brazilian woman image

\begin{abstract}
Resumo
O presente trabalho se propõe a realizar uma análise inicial sobre a formação da imagem da mulher brasileira considerando o discurso historicamente construído e reforçado na fotografia colonial. Tal visualidade resiste através dos tempos, consistindo em uma forma de colonialismo contemporâneo por caracterizar-se como uma ação reducionista das identidades, em dissimulação de uma ideologia globalizada. A possibilidade de criação de paradoxo a esses discursos é analisada por meio da reflexão dos trabalhos de André Cepeda e Miguel Valle de Figueiredo, fotógrafos portugueses que possuem trabalhos fotográficos acerca da mulher brasileira. Nestas fotografias, a construção da mulher brasileira revelou discursos apoiados em percepções e experiências, como também em atribuições de valores generalizantes. Deste modo, concluiu-se que o entendimento sobre a imagem da mulher brasileira, conforme olhar desses fotógrafos, se mostra revestido de novos processos colonizadores em que à imagem da brasileira associa-se um corpo disponível e sensual, impreg nado pela compreensão de um corpo colonial que ainda persiste no imaginário contemporâneo.
\end{abstract}

Palavras-chave

Visualidade; fotografia; colonialismo; imagem da mulher brasileira 


\section{INTRODUCTION}

The emergence of photography in the $19^{\text {th }}$ century brought with it the assumption of an indisputable truth about the facts represented. Its status as a purely descriptive medium allowed an understanding that when registering the "real" world it does so in the most objective way to see something as it "really" is. This provides one's remembrance with an understanding that the facts were presented in a picture as they really looked like. Therefore, memory and photographic image are mixed, one seems not to work without the other.

However, both photograph and memory are not sufficient to confer absolute credibility to a given fact. As memory, photography selects parts of the event to deceive, manipulate or enhance ideologies when characterizing a subject in a specific way. Nevertheless, photography still constitutes one of the best tools for recalling processes (Le Goff, 2003).

The photograph, at same time that allows the remembrance of what is seen in it, also allows to its author a construction of a stigmatized image about people and places, dictated by the underlying intentions of its maker. Even when photography is used as a technical document, it also enables the creation and profusion of meaning. Through this process, an identity definition of that Other is unveiled. In the colonial era, photography was responsible for printing racist notions which represented often a false depiction of events, subjects and historical circumstances (Roberts, 1988).

It is known that gender relations went hand in hand with photography by giving an inferior role to non-European women, through the display of an image of a naked available body presented to the colonizer. This "male gaze" in image making marked the colonial age, especially when it started to register civilizations and individuals who were apart from the European ways as inferior beings, wild and disabled. Such use of photography created the concept of colonial photography (Edwards, 2008), one that registers the colonizer's view and lays himself in a place of superiority relating to those being captured by his camera, unveiler of the "unknown and barbaric" world.

Thus, photography became itself a diffusion medium of cultural asymmetry and gender since its invention. Pictures populated collective imagination of European people, who have come to know the world through images made by traveling photographers. Because of this same memory element that pervades photography colonialist ideas are still repeated in contemporary images, and are seen mainly in the replication of patriarchal and imperialist character stereotypes, ideas confronted by feminism and post-colonialism.

The almost zero presence of women as social agents in the colonial era is reflected in such representation of the female body as seen by the male gaze. There was a constant surveillance of manners and appearance and therefore, the image of women sought to reflect her own "good manners". This idea of modesty was not imposed by men only, it was also inculcated in the minds of women to the point of developing a self-monitoring awareness, being thought to do so from childhood on (Berger, 1972).

Therefore, one must understand that the male gaze is more than "the way a man looks to" something, but also a place of meaning formation. According to Laura Mulvey 
(1989), a woman can also have a masculine "gaze" whilst in position of observing another woman in a picture, reviving a lost aspect of her sexuality while doing it. The woman represented through an objectified view in film seems to provide the woman-spectator a place of male gaze and pleasure. Thus, the female body-object gives her a way to access an "aesthetic curiosity" (Mulvey, 1996) that counteracts a sexist scopophilia.

The whole package of women's imagery is held as "not a history of illustration, but as a story in itself" (Higonnet, 1992, p. 140). In these images, the representation is seen as "rules of language function that reveal or distort what is held to be true about the category of women" (Butler, 1997, p. 18). With the awareness of visual image's normative function, we seek to go deep beyond surface and get away from common sense and old ideas" contamination that settles like stains on the visual image of Brazilian women.

This reflection is aimed to propose a brief analysis of the construction of a visual representation of Brazilian woman as viewed by Portuguese photography. To accomplish this purpose, this paper aims towards a theoretical view about the image of women's body, as well as a historical look at Brazilian women's image as portrayed by colonial photographs and Portuguese newspapers. Based on that, it has been proposed an analysis of art projects made by two contemporary Portuguese photographers: Miguel Valle de Figueiredo and André Cepeda. Both of them were in Brazil and Brazilian women were portrayed in their works.

\section{THE IMAGE OF WOMAN'S BODY: OBJECTIFICATION AND FETISHISM}

The body, directly or indirectly, displays a lot of issues that are extremely significant: notions of race, concept of beauty, sexuality, beliefs and notions of morality, as also the distinction between "wild" and civilized. To William Ewing (1996), pictures that have the human body as subject are political, since they are used to control or influence opinions and actions. This type of image achieves greater impact on social imaginary that television images. Pictures are the raw material of what gets carved in collective memory as the identity of the other.

When it is displayed in an erotic way, the view of a body depends on the types of such bodies' social classification. The washerwomen, since working in open spaces, were considered women with a lost sexuality (Henning, 1996). Even today, the erotic photography operates under a classification of its themes organized into recognizable types. For its part, the Advertising industry has been representing a woman's body using several degrees of explicit nudity or sexual activity in order to eroticise the female body and turn it into an object for the male gaze. For Michele Henning (1996), this is what is called objectification of the female body.

This concept is especially relevant when it comes to photography, as it also brings objectification to a second layer when it turns people into simple objects for sighting. For Solomon-Godeau (1991, p. 237) "the most insidious and instrumental forms of domination, subjugation, and objectification are produced by mainstream images of women rather than juridically criminal or obscene ones". For the author, History of Photography 
itself is intertwined with the social history of women, given that photography brings in its tradition a voyeuristic or fetishistic trait when portraying women.

The word fetish comes from Latin facere, meaning to make or to build. This word was first used in the $15^{\text {th }}$ century by Portuguese settlers and merchants when referencing to the African reverence for religious amulets and idols, being used then with a direct reference to witchcraft practices. Fetishism would then be the act of worshiping a fetish (Hirschfeld, 1982); to incorporate a magical property to the fetish object. This includes the Christian iconolatry that attributes supernatural powers to its saints, who could also manifest effects miraculously on the physical level.

In psychoanalysis, an object becomes a fetish when it is focus of a sexual desire, often associated with women. This is because the fetishist idealizes articles associated with women, such as shoes and lipstick. For Freud, in Three Essays on the Theory of Sexuality, written in 1905, this is an aberration, almost a condition as it replaces the "normal" sex. Fetish is "a substitute for the penis in a woman (in a mother) in which the little boy once believed and - for reasons familiar to us - do not want to leave (...) because if a woman was castrated, then the possession of his own penis would be in danger" (Freud, 1974, p. 180). According to the father of psychoanalysis, the choice of the fetish object does not depend on the similarity to the penis but to the period of fracture or trauma occurred in early childhood, when the boy realizes that the mother does not have a penis. It is at this moment that the first object that is seen then becomes your fetish, derived from own castration anxiety.

The relevance of this aspect of Freudian theory to the study of photography is that it serves as a tool to explore how visual images can objectify and fragment the woman's body, a phenomenon that happens in a totally different way than regarding the viewing of the male body shape. However, there is a problem: the fetishism is based on male castration and therefore qualifies only as a male-related issue, ignoring that it may arise in other genres. The female body is then shown as the vessel for the fetish desires fostered by males.

In this sense, Christian Metz (1985) relies on Freud to state that photography and fetish carry in it both the same contradiction and uniqueness. While the picture steadies time and allows us to carry with us a visual image, fetishism freezes a moment and fixates it in the fetishist's memory. The fetish suggests that photography summons the dead and at the same time keeps one's memory in the past. Its temporal simultaneity and material dimension allows to the photographic object its fetish character.

The film critic Laura Mulvey also uses psychoanalysis to establish a profound critique of women's visual image, especially in the cinema. In this context, psychoanalytic theory was used to unravel how the "unconscious of patriarchal society had structured film form" (1975, p. 06). In Visual Pleasure and Narrative Cinema (1975), she speaks of the existence of a male point of view that is shown in the visual arts and literature. This "male gaze" can be seen through constant use of close-up framing by the camera to show body details, hence fragmenting a woman in mind of the viewer. While backing up in fetishism theory, the author speaks of women's objectification from the point it starts to 
be represented as spectacle. In this sense, the man (heterosexual) constitutes the look in itself and the image to be viewed is a woman. These roles are wrapped by castration complex, where the woman is seen as the lacking or deprived portion, the sex difference. To escape from castration anxiety, the man places the woman in an undervalued position as punishment (voyeurism) or replace the female figure by a fetish (object of desire).

Later on the essay however, the author sees fetishism not as belonging to a dominant sexual look but as a culturally dominant way of seeing the world. Through the article "Afterthoughts on 'Visual Pleasure and Narrative Cinema' inspired by King Vidor's Duel in the Sun (1946)", Mulvey (1989) updated her line of thought with the inclusion of two other elements: the woman as spectator and as also in a female protagonist role. While in spectator's place, a woman mirrors the "male gaze" which is nothing more than a stance in the world, a proposed way of seeing through a masculinized version of the viewer's place. The woman takes a manly place to revive the lost aspect of her sexuality, the castration itself, using this proposed form of gaze and its pleasure. From the moment she displays masculinity as her viewpoint, she is no longer passive.

In search of a perspective beyond a binary or simple male and female opposition, Mulvey develops this theory further in Fetishism and Curiosity (1996). For the filmmaker, the woman as spectator performs a function similar to Pandora when opening the box. Curiosity exerts fascination by the image and therefore, it is shown as source of knowledge. Throughout that line of reasoning, she develops the idea of an "aesthetic curiosity" to counter the male gaze that fetishizes the image binding the curious look of Pandora to the box. She transforms the myth that had a misogynistic significance when showing the woman as guilty for all the evil of the world in a curiosity that has political dimensions in interpreting images. "While curiosity is a compulsive desire to see and to know, to investigate something secret, fetishism is born out of a refusal to see, a refusal to accept the difference the female body represents for the male" (1996, p. 64).

When proposing an epistemophilia as resistance to sexist scopophilia, Mulvey (1996) suggests still the need for modulation of the argument itself to allow a more satisfactory relationship between fetishism and curiosity. Therefore, to reflect on image of women is to know that it is composed of a complex web of meanings acquired over time, that its representation has political meanings and its reception is located under the "male gaze" or even beyond, in a two-part look broken into male and female sides.

\section{THE PHOTOGRAPHY ROLE ON THE IDENTITY CONSTRUCTION OF THE “OTHER"}

According Juan Naranjo, introducing book, Fotografía, antropología y colonialismo (2006), the advances in image printing technology starting from the early $19^{\text {th }}$ century allowed a considerable growth in circulation of printed images comparing to previous centuries. The proliferation of optical devices' use in both public and private sectors changed social habits and introduced changes in the forms of reception and distribution of information. Considering just the second half of the $19^{\text {th }}$ century, it has been created a widespread "visual industry" with an incredible iconographic density. 
Photography started to play a key role in cultural changes especially from the point images were placed next to printed words, despite the photograph's ability to erase boundaries between reality and its representation. It was exactly this ability of illusory mimesis between an object and its image as also its multiplication capacity, which made photography the visual medium of widest social penetration. Advances in photographic processes made possible the emergence of its industry, opening venues to commercialization of large-scale photographs at cheap prices like the cartes de visite. By acquiring widespread acceptance, photographs started an extensive process of democratization of visual information, since the acquisition of a picture replaced the direct live experience for a virtual observation of people and landscapes of distant locations.

Due to the expansion of the photographic industry and increased consumption of photographs, many companies extended their offer and inventoried the world sending photographers all around the world to document what they saw, as if it was an urge. At the same time at distant sites numerous photographic studios were open and to fulfill a dual function: to photograph local bourgeoisie, settlers, missionaries, sailors and also to record types of humans who were arriving in the main cities and ports. The goal of that last kind of production was the acquisition of these images by travelers and tourists.

The start of that trend of great circulation of photographs transformed into a "familiar" view the image of the "other", both for scientific class as for the bourgeoisie of that era. Although some researchers such as anthropologists used the colonial pictures for analysis at expense of field research, other scholars challenged the veracity of these images pointing them as staged as cartes de visite, once they had primarily a commercial potential. The dissenting scholars asserted that these pictures had predetermined formal standards so that the information would bring a better reading or to facilitate the comparison and therefore, it would rarely serve as basis of serious scientific studies.

The photographs taken in European colonial period had themes invented in generic ways and there was no effort at the time to identify the photographer and the event in depth. Therefore, one must lean on the colonial era photographs critically', an important challenge for those who use the photographic analysis in scientific research today.

The contamination of European behavior standards in the ways of life of portrayed non-European tribes - which often led to the total destruction of these cultures - is another factor responsible for making unusable the colonial commercial shoots in anthropological research material, once the cultural contamination itself was a direct result of the rapid process of colonial expansion in the $19^{\text {th }}$ century. Much of this genre of photography reproduced all kinds of fantasies related to Orientalism ${ }^{2}$ and other exotica. Thus, these photographs were used to create stereotyped identities meant only to satisfy the European Romantic consumers.

\footnotetext{
'To this regard, see the Photo Clec Project (Photographs, Colonial Legacy and Museums in Contemporary European Culture) available at: http://photoclec.dmu.ac.uk/.

${ }^{2}$ Orientalism, as seen by Edward Said (1978), is related to the subaltern treatment of the "Other's" culture. It is a critique of the phenomenon of Orientalism, defined as "a set of ideas circumscribed to values, presented in a generalized way, mentality, and characteristics of the East". In this way, the dominant culture takes over the other and translates it from its own grammar and imaginary when describing the culture of the Other. It ends by establishing categories and values that are based not on reality but on the political and social needs of the West.
} 
There is also strong gender relations that permeate photography of the colonial era with the attribution of an inferior role to women, especially those with non-European origins. Photos of half-naked or even naked women, regardless of race and what colonized country is in question, are always present in the colonial visuality. Such event can be explained according Filipa Vicente (2014, p. 22) as "resulting of a domination posture in relation to the visible - in relation to what can become visible -as well as the male hegemony in the colonial space. "Among the ethical problems that these images put, Vicente (2014, p.m26), when faced with the sculptural works of Vasco Araújo entitled Botany (Figure 1), points out: "but if she were his woman, wife, white, in a Portuguese village and not in Africa, the Portuguese soldier would let himself being portrayed just like that by anyone?"

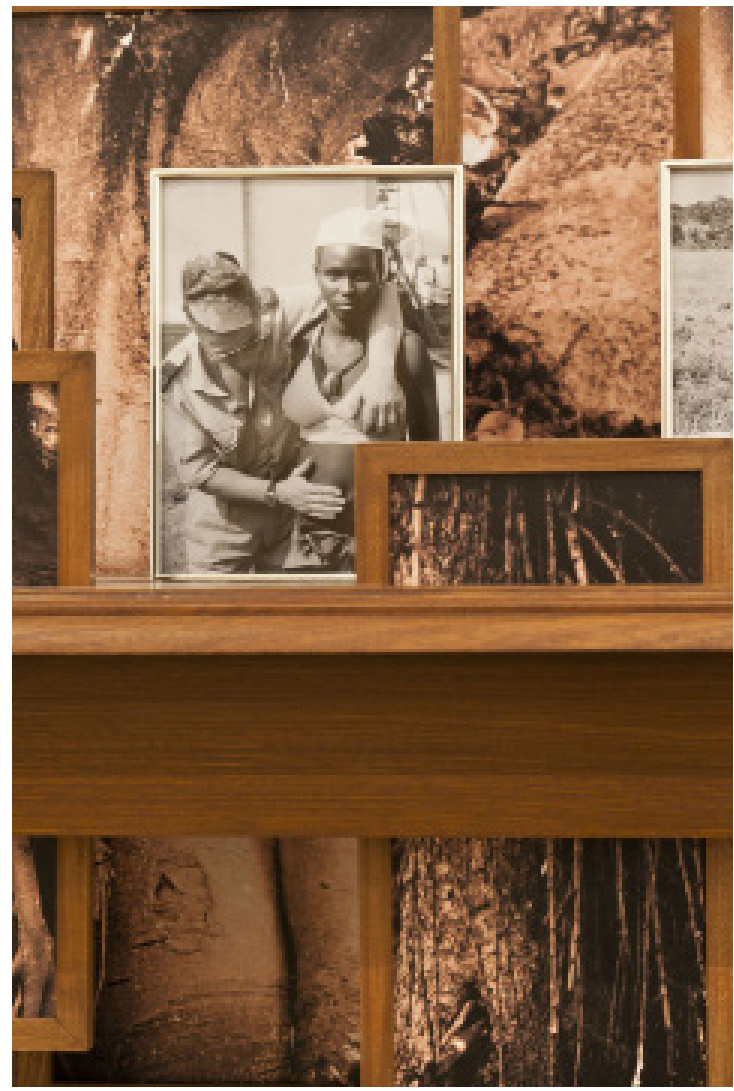

Figure 1: "Botany" exhibition, sculptural object detail, Vasco Araújo, 2014 Source: http://www.museuartecontemporanea.gov.pt/programs/view/5

For Stuart Hall on Cultural Identity and Diaspora (1996), representation practices always involve positions from which we write or speak. The characterization of the "other" contributed to creation of categories of religious, racial, sexual and gender content articulated in different ways. This superficial purpose of differences identification played a key role in Western visual culture. By creating the "other" as a disqualified being, inferior to West's power and knowledge, Western production was established as a form of hegemonic knowledge. Thus, it used and hijacked the very existence and culture of the other in the name of its superiority. 
This dialectical world view which opposes the colonizer and the colonized and assumes the settler culture is superior to the last, in addition of fabricating a subordination relationship of the "other", deeply imprinted the idea of inferiority in mind the "other" with the purpose the latter considered himself unable to combat this whole logic. (Barradas, 2009). Often photography was responsible for building an acceptance of such authoritarian power over the subject photographed, a power that also controlled the production and distribution of images.

This asymmetry of power led to the conclusion that black people, especially women, are sub-humans or animals. The images showing a woman in eroticized positions with apparent nudity and sexual availability to the eyes of a white settler are factors that put her not in an immoral world but in an amoral one, because her very existence was rooted apart from those standards required by moral colonizing.

In the context of the colonial relationship, says Maria Baptista (2013), "it is necessary that the black people shut up, have no face, identity or memory" (p.284) and "thus they can barely exist to the white people eyes, for they have to be objects of conquest and ordering" (p.285). Photography in this context was used as form of appropriation of bodies, memories and identities of the Other to represent him out of the historical process and time, as an uncivilized being.

\section{The image of Brazilian women as seen by the Portuguese gaze}

The invention of the "Brazilian" cliché, or the creation of a visual that could be translated to certain group of individuals as the original inhabitant of the "New World" is a product of history of Portuguese immigration in Brazil. In addition to the "Brazilian" term being representative of a wild barbarian, it was also used to represent the Portuguese emigrant returning from Brazil. According to Jorge Fernandes Alves (2004), the consequent lack of opportunities due to economy marked by farming and stagnation of economic growth in Portugal assigned to Brazil the possibility of a better future for individuals, as to "Emigrate meant to meet aspirations built in confrontation with environment and its social representations which appeared as dominant, supported by the case of real and close characters" (Alves, 2004, p. 195).

In Brazil, many photographers focused on the port regions where slaves and authorities disembarked. Among Portuguese photographers in Brazil, it was the Azorean José Christiano Junior who owned the largest collection of photographs of slaves held by 1860 . With a collection consisting of 77 pictures, he offered his customers "a varied collection of customs and types of black people, the very own thing suitable for anyone who retires from Europe" (Gorender, 1987, p. xxxi). As the author photographed slaves in the exercise of their functions (Figure 2), which shows the interest of a classification of existing Brazilian individuals, there were photos that refer to black women as exposed bodies available to the eye of the photographer and the buyer. Women were shown naked, objectified, which relates to how slaves were examined to their details in markets. As pointed out by Freitas (2011, p. 65), the female slaves were lust targets for lords and 
were subjected to all sorts of actions in the sexual sphere, since they were "perceived as mere objects" who "gave vent to sexual impulses".

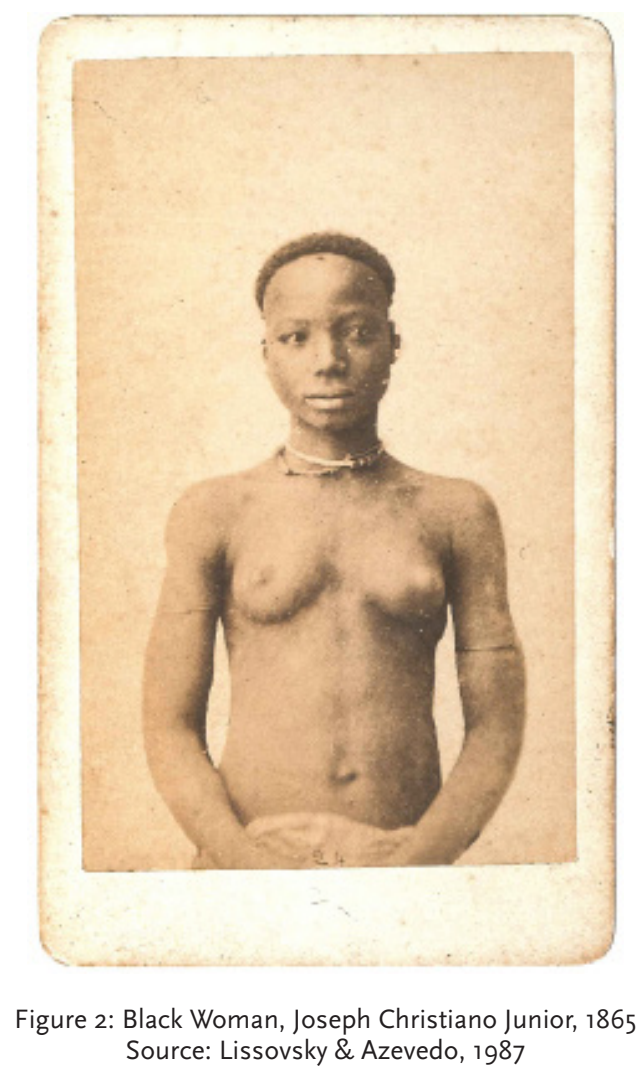

Black people of the colonial era constituted over half the population of Rio de Janeiro, capital of the Portuguese empire at that time, being a "so expressive contingent that chroniclers of the period came to compare the Rio landscape to the cities of the African coast" (Lissovsky \& Azevedo, 1987, p. xxii). Christiano Júnior had in his cartes de visite "types of black people", as black individuals were portrayed from their front and side to side to show facial features, tribal branding and clothing to highlight the characteristics that defined one's ethnic group and / or profession (technique known as Bertillonage).

These photographs, according Lissovsky and Azevedo (1987), were directed to the public that has been isolated from the world until 1808, year in which opening of Brazilian ports to international trade happened, a concomitant occasion with the installation of the Portuguese Court in Brazil. It is a set of images that evokes human types and crafts; basically those are pictures of an alien and foreign. It is important to highlight the changing of senses reaching the carte de visite, namely, if there was the image of a man of means, that picture could then become his business card; however, when it presents a black person the picture would have the function of a postcard of Brazil. While the former describes a dignified individual, the latter describes a picturesque and generic character (Cunha, 1987).

Importantly to say, there was always a association of a sense of virility to black people, resulting of a hyperssexualization inherited from the colonial period. This prerogative attributes the look at sex as mean to authenticate an imprisonment "in geography 
and skin color" (Pine, 2004, p. 67). The hipersexualized black individual in the picture removes his nature as a human being to make way for an animal, a fetish.

According to Luciana Pontes (2004), who parts from a fieldwork carried out in Lisbon about women as portrayed in the media, "the recent intensification in the late 1990s of the Brazilian immigration further complicated mutual identity processes in a context in which are created and / or enhanced old representations" (p. 236). In these representations, the author points out to a process of essentialization and exoticization of Brazilian national identity in addition of the sexualization of its women. This issue, as seen, follows the very formation of Brazil and the use of colonial photography to represent the "other".

It can be seen that sexualization of Brazilian women in contemporary images repeats several standards set in colonial photographs era. The sexualization process of Brazilian immigrant women arises in connection both to the immigrant condition as being from a country that has a colonial and slavery past. There is an overlap of social markers of exclusion - colonialism, sexism and racism - which only reinforces the colonial / subordinate and sexualized position.

In Portuguese journalism, the relationship between Brazilian image and prostitution was propagated more intensely from the case known as "Bragança Mothers" in 2003 (figures 3 and 4). This occurred, as descripted by the news outlet Times Magazine, as a result of a protest carried by Portuguese women against the presence of Brazilian women who were in Bragança to work in brothels. Wives decided to unite and oust that families' "destructive" individuals. This case contributes up to the present for a general association between Brazilian women and prostitution. This event resulted in closure of swing houses, arrests of some women and repatriations of illegal Brazilians. For the Portuguese press, those were actions necessary to ensure that women of "easy sexuality" are not allowed to invade the private space reserved for the family.
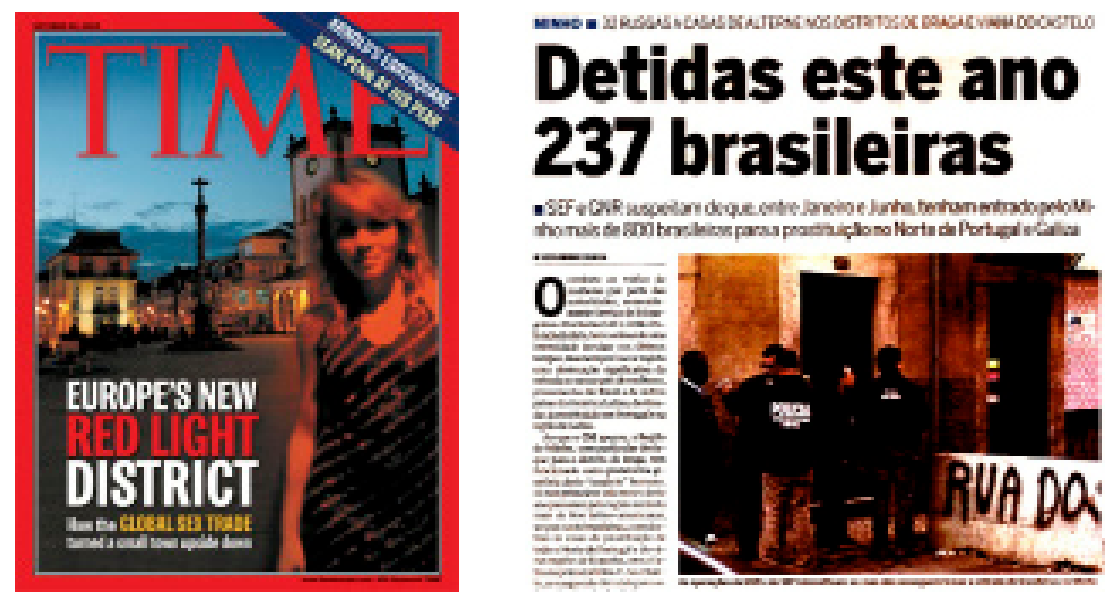

Figures 3 and 4: Cover of Time magazine that draws Bragança "Europe's New Red Light District" and a newspaper clipping which shows the arrest of Brazilian ladies in the Portuguese press 
For Gomes (2012), the Portuguese press has been important to that association of Brazilian immigrant with prostitution. An example of this can be seen in the controversial issue of the cover 565 of the Portuguese weekly magazine Focus (Os segredos da mulher brasileira, 2010) (Figure 5). On the cover, a woman wearing bikini serves as background to the headlines: "The secrets of Brazilian woman: He absolutely loves it, she hates it", "2,216 marriages with Portuguese men in 2009 alone" and "the Ten commandments used to seduce men". In that story, the Brazilian are defined as coming from "Vera Cruz", name that Brazil received earlier in the colonial era, which shows an explicit approach to the imaginary of that time. In addition, the Brazilian woman is represented in a fragmented manner, exposing part of her body as a sexual object.

The brazilian woman as seen under the stigma of a "colonial body", will always be the bearer of an available body, seen as object and understood as a constant "threat" to the Portuguese family. This available and sexualized body image touches all Brazilian women, regardless of her function in society or level of education. The differences in social class condition and education of Brazilian individuals seems to influence the vulnerability to stigma. Women with low education and low income when exercising household or customer service activities are targets of greater prejudice. Organized reaction capacity against that prejudice is also lower in the most vulnerable group, so they end up by accepting and internalizing the idea of being from an inferior culture (Gomes, 2012).

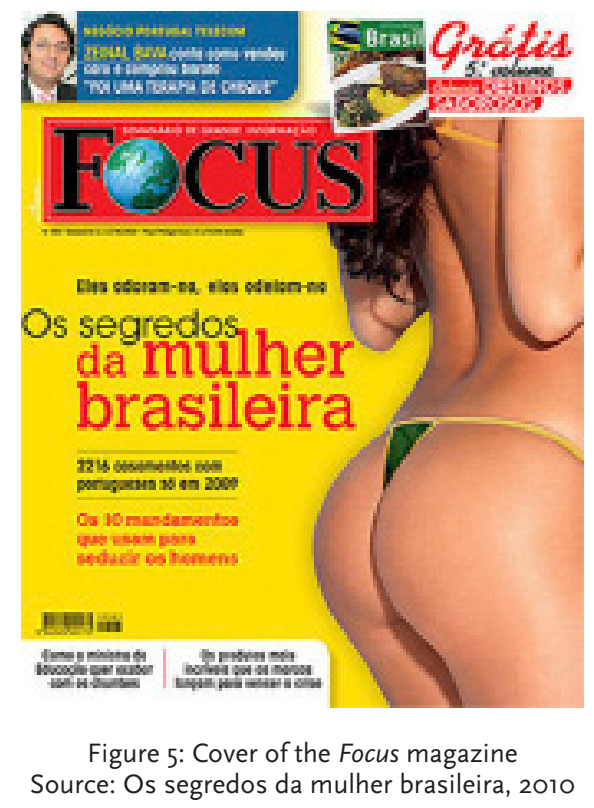

Currently, tourism businesses and advertising have great weight in the spread of the image of an exotic Brazil to present mixed race women with a naked body as an attractive in tour packages. This has changed somewhat, says Gomes (2012) as the agency responsible for Brazilian tourism and the Portuguese press are currently deconstructing the imagination of the mulatto and eroticized woman, to construct other imaginary of Brazil with the presentation of cultural elements instead of exposed bodies. This is due in part by pressure exerted by Brazilian social movements in Brazil and Portugal. 
The image of Brazilian women in the Portuguese Contemporary photography: André Cepeda and Miguel Valle de Figueiredo

The existence and action of the individual in his reality as it presents itself is conditioned by the different ways of looking at the world, to interpret it and to possess it. It is through the double distance between the image and what it represents and the image and the being who stares at it, which are concomitantly found both the meaning and loss: a construction of meaning of what is represented through an articulate speech by culture itself, and the loss of the object / subject in its very existence caused by the opacity of its own representation. Thus, the construction of visual images is understood as a process of recognition which settles one's belonging or strangeness sense and one's relationship with reality.

While images broadcasted by the daily informational and communicational outlets cause "a stultifying massmidialization" (Guattari, 1992, p. 16) of a large number of individuals, a significant portion of the images made in the context of contemporary art and design principles aim to promote experiences that enable the generation of paradoxes regarding the current aestheticized reality. The experimentation of this paradox can point to a construction of a criticality relative to agency procedures laid down in cultural current globalizing system:

this poetic-existential catalysis, as we will find in operation within scriptural discourses, vocal, musical or plastic, engages almost synchronously an enunciative recrystallization of its creator, the interpreter and the work of the art connoisseur. Its effectiveness lies primarily in its ability to promote active, procedural ruptures, within the field of meaning and its denotative semiotic structured fabrics. (Guattari, 1992, p. 31)

The poetic construction of the artistic object, according Guattari, has a power of deconstruction of generalizing statements, since it offers the viewer a distorted meanings system consolidated in / by the current globalized culture, expanding sensitive possibilities of individuals. Such an object, even though its triviality, displays the otherness, since contemporary artistic aesthetic constitutes itself in the opinion of Ferry (2003, p. 31) as an extension of the artist himself, "a kind of business card especially designed" which present themselves "as so many 'little perceptual worlds' that no longer represent the world, but the state of vital forces of its creator" (Ferry, 2003, p. 32). Thus the familiar image is contiguous to the strangeness, by revealing not just a speech of what is seen as strange, a discourse created collectively by its context as formerly done: It also offers the creation of an intersubjectivity through the possibility of dialogue with the world created peculiarly by that artist.

Given such prospects, we seek to analyze the visual created about the "Brazilian woman" in images produced by André Cepeda and Miguel Valle de Figueiredo. The choice of these two photographers also aims to an approximation of how the Brazilian woman is still perceived in the Portuguese photography due to the colony relations maintained with Brazil. In this article, our interest is to reflect about the references found 
in those images assigned as identity of Brazilian women to see how this influences the recognition of Brazil in contemporary times, in the specific case expressed through the eyes of these photographers.

It has been noted that according the postmodern reflections of photography each image references the other, constructing parallels, diachronies, synchronicities and dialectic forms, building a web of significances beyond the author intention. In this perspective, "the photographs were seen as signs that acquired its value from its insertion in the midst of a broader system of social and cultural encodings" (Cotton, 2013, p. 191). Thus, this is what is meant to be seen here through the works presented: pieces of a wide historical, social and political fabric which emerge from different relationships, including the Colonial ones.

\section{André Cepeda, Stan Getz Street (2014)}

André Cepeda (born in Coimbra, 1976) lives and works in Lisbon. Since 2005 he has been working continuously regarding Portuguese contemporary landscape as him subject, particularly the Porto region landscape. According to the photographer, he uses a large format camera $(4 \mathrm{~m} \times 5 \mathrm{~m})$ because it constitutes a more precise tool that would allow for a more accurate technique. To obtain those results the equipment requires a slow process of work, thus determining his method: a long and close observation of things that would allow him to connect to and / or relate to the object or landscape he wants to photograph.

The photographer states in his website ${ }^{3}$ that he is interested in building new ways of looking at reality and space that are presented to him. Essentially for him there is a quest in his work for spaces and moments that have been rejected, suggesting a certain suspension. His interest, therefore, is based on the feeling that makes him compelled to create an image and report its space, trying to forget its history and original context of reception. Thus, he has the sole interest of work in the light, space and time of a scene. In this way, he feels freer to create new contexts for the images, as if this almost sculptural treatment would retake a dignity that was denied to the object / landscape. For the photographer, these images become a time of broader reflection about the way we build our cultural, social and political identities.

The selected artist's work in the city of São Paulo, in Brazil, took three months of reflective gaze and artistic pathways that led him to a different and peculiar city ${ }^{4}$. This is a more of a sculptural work, which reports the space selected by the photographer. The images taken mix flânerie experience by the artist who present us streets, passersby, landscapes, city space reflections in his lens, aiming to record his gaze on the path taken. The result of this experience resulted in the book Stan Getz Street (2014) which also features portraits, mostly composed of naked women (Figures 6, 7, 8, 9). Those are

\footnotetext{
${ }_{3}^{3}$ Available in the section About, at http://www.andrecepeda.com/

${ }_{4}^{4}$ This information is based on the fragment "São Paulo em corte" by Agnaldo Farias, published in André Cepeda's website, available at http://www.andrecepeda.com/projects/ sao-paulo-em-corte/.
} 
women of peculiar bodies, building the idea of an ethnic diversity in Brazil by displaying "the skin tones diversity" 5 . The author states that he used living models who are used to pose in the Faculty of Arts of São Paulo da Fundação Armando Alvares Penteado (FAAP) in his photos.

In this photo essay, the photographer uses a larger number of female nudes in comparison to others he previously made. When facing the pictures of this Brazilian project, it is impossible not to find colonial ethnographic references and even classical painting references. The author said in an interview that women are presented without clothes to follow the History of Art traditions.
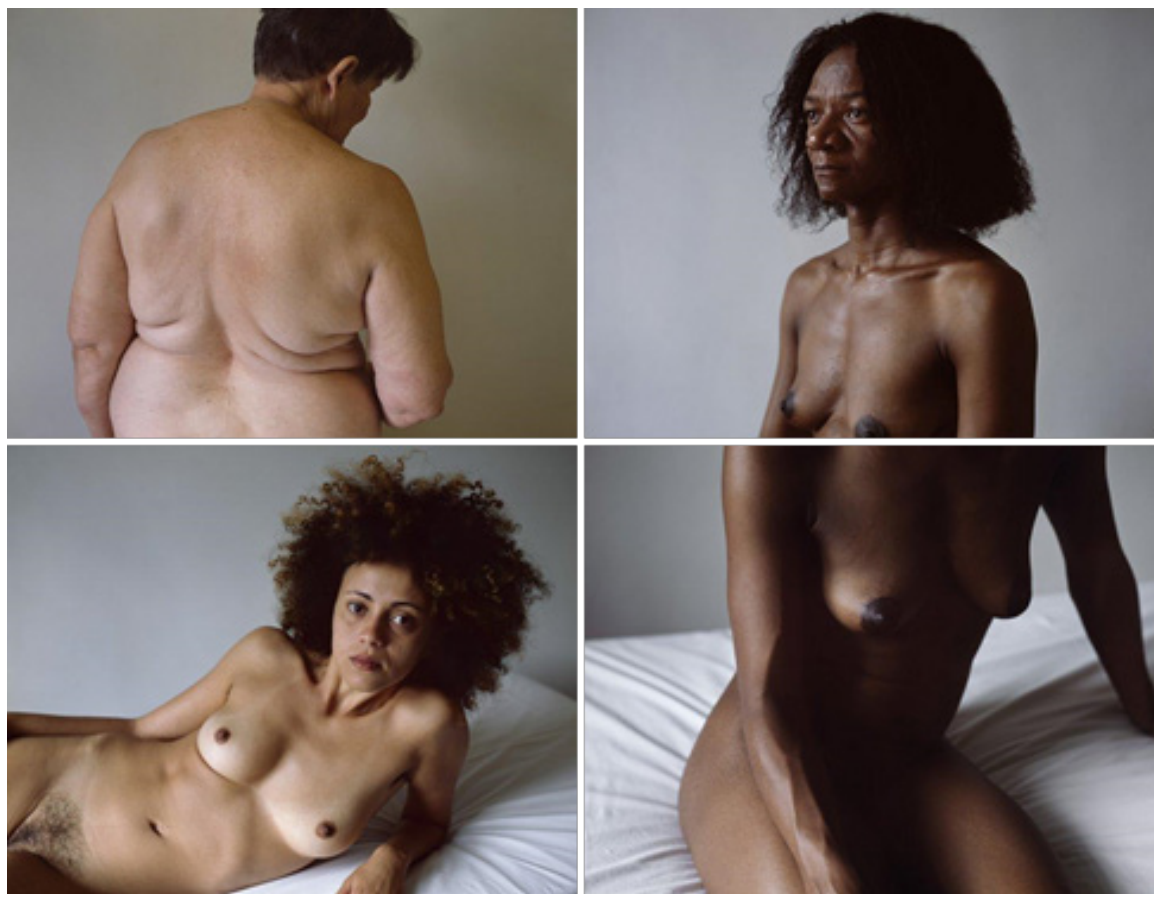

Figures 6, 7, 8 \& 9: André Cepeda, Stan Getz Street, 2014 Source: http://www.andrecepeda.com/projects/rua-stan-getz/

As a reference to the classic painting, we take as an example the picture in which a naked black woman (Figure 8) is reclining on a bed (the reclining nude is quite traditional in painting, as well known). In it, one can follow the temptation to repeat the statement that this woman by acting out the classic pose of the painting traditions displays herself up as an erotic object. Her stare, aimed to both the photographer and to the viewer, makes her objectified twice (Ewing, 1996). But the woman in question by working as a live model for painters, she deliberately uses bodily performance in the picture to represent a classic pose which is often used with various symbolic ${ }^{6}$ assignments.

\footnotetext{
${ }_{5}$ The interview was conducted under the lecture talk with the artist in "Summer School of Photography: File, theory and history" organized by Filipa Lowndes Vicente on 22 September 2017.

${ }^{6}$ When Manet painted Olympia (1863), he had the Vênus de Urbino by Titian as his inspiration. However, instead of painting under the accepted artistic tradition, with biblical or mythological subjects, he prefered to paint a real woman, perhaps a prostitute in the role of Venus. Olympia reclining in the same position as the Venus of Titian casts the viewer a powerful and confusing gaze. Thus, Manet denied the strict classification of female sexuality represented by traditional painters.
} 
In this context, "to recognize oneself in a portrait (and in a mirror) one imitates the image one imagines the other sees" (Phelan, 1993, p. 36). The pose itself is a theatrical attitude that provides an image already taken "from a set of standards, which is a piece of the perception of one's social self" (Fabris, 2004 pp. 35-36). The portrait, by being taken as a representation of what the other sees ends to represent the "male gaze" of the woman acted by the woman herself. As in Manet's Olympia (1863), the picture starts to be formed by folded meanings between what someone is and what one should look like. To generate another image of or to oneself, the picture becomes a sort of simulacrum. In this game, the woman's self-image reflects the male point of view, a place that determines how it should be her pose and, therefore, her own representation.

Regarding the ethnographic style of remembrance in his work, it is highlighted here the picture showing a black woman, naked, who is set to show her profile and without staring at the camera (Figure 7). Cepeda assumes, such as colonial photographers, to represent the wide variety of skin gradations in this small inventory of women who he met in Brazil. According to the website of the author, he tries to forget both the story and the original context of response to the subject. It can be seen that in amidst of the author's desire to forget all of Brazil-Portugal colonial history as well as the representation heritage of women, he ends up representing the Brazilian woman whit triviality and aside from social and political concerns that may be associated with the exploited body.

Yet, it is imposed to the viewer's judgement a single portrait of a male individual throughout the whole book (Figure 10), who is fully clothed. Judging by the thought of Cotton (2013, p. 191), the image acquires its value "from its insertion in the midst of a broader system of social and cultural encodings". There is a strangeness to the viewer caused by the female nude when contrasted with a serious and dressed man.

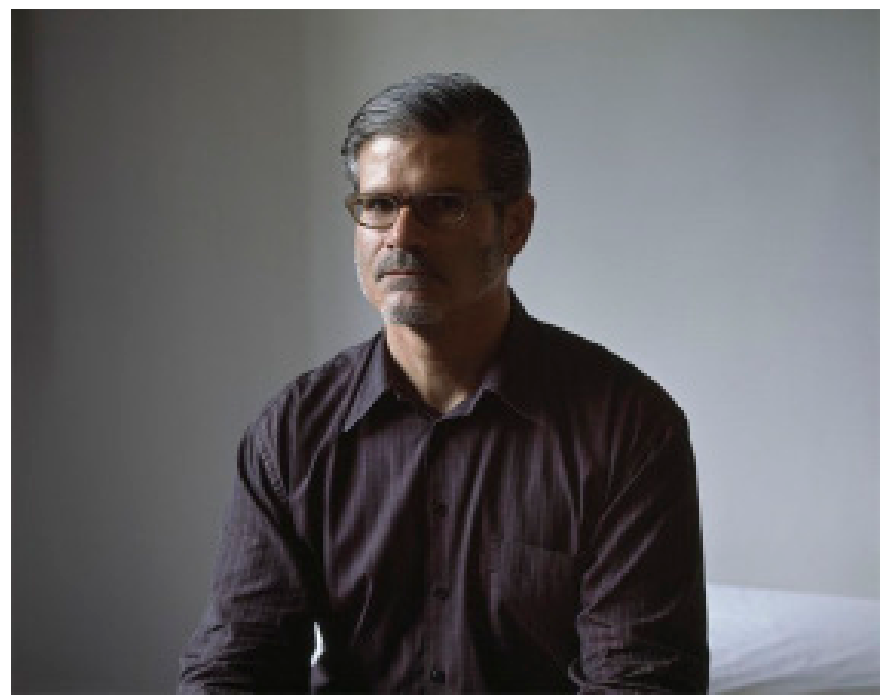

Figure 10: Stan Getz Street, André Cepeda, 2014 Source: http://www.andrecepeda.com/projects/rua-stan-getz/

In the book Stan Getz Street (2014), there are no explanatory texts that show any patriarchal slant on his images. However, making a counterpoint to the discourse of 
the photographer, - who replicates same the representation of women used in painting traditions, he exposes a sexist and careless look about the cultural and historical context of the individual photographed -, his photo essay ends up in displaying visual images of Brazilian women that strengthen the colonial stereotype fought by feminism and post-colonialism.

\section{Miguel Valle de Figueiredo, Brazil (2007-2008)}

Miguel Valle de Figueiredo was born in Santa Comba Dao, in the district of Viseu, Portugal. He is a professional photographer since 1986, with works in the industrial, engineering / architecture and editorial fields. In 1994 he was a co-founder of the magazine Around the World, a publication aimed at exposing possible courses of travel, carrying out reports in more than 50 countries. Miguel has been in Brazil about 30 times, two of those for holiday times. The author claims to know Brazil more than many Brazilians. In 1997, he won the Award Fuji-European Press in the category of In-depth Stories, with one of his photos taken in the state of Ceará, Brazil.

In a conversation with the photographer, he points out that his forays into Brazil are result of his work for tourist publications and for this reason many of his pictures are no exception to the main iconography attributed to the tropical country of beautiful landscapes and homeland of Girl from Ipanema. But in his speech, Miguel Valle de Figueiredo explains that this myth about the Brazilian woman, created by Brazilians themselves, it doesn't really exists, because in the country extension every Brazilian woman is singular - with its peculiarities on her walk, speech, her actions.

However there aren't many photographs of women in his work, arising instead as a more predominant subject the "exotic" landscape in his online portfolio presented in his Flickr page. The author, however, photographed peculiarities of a continental Brazil tinted by inequality. It seems that when he bring to us the specificity of Brazilian small villages and its people, as seen in the northeast region, the author accentuates this inequality and opens a wide sight to a not so generous features of the country such as those advertised by Caminha's letter at the time of the Portuguese conquest. That same conquest of paradise nature generated, in fact, many "Brazils". This Brazil, shown in his award-winning photographs, reinforces the idea of a mestizo country and presents the paradoxes and contrasts in the ways of life of individuals and societies that make up Brazil as a nation.

By having a practical advertising nature, a woman display in his pictures comes along with the landscape as an exotic representation of the site. There is an exotic and sensual beauty that is supposed to belong to Brazilian women, legacy of colonial vision imposed on black and indigenous people who were seen as polygamous and incestuous (Vanifas, 1997). It was up to the photographer in his commercial work, the task of playing The Girl from Ipanema, Tom Jobim's music that was responsible for idealizing women of Rio de Janeiro (Figure 11). As also never absent in the Brazilian cliché representation in travel photography, nature appears as the habitat that shelters the woman, half naked, wild, like a Medusa who seems to mesmerize men she meets (Figure 12). 

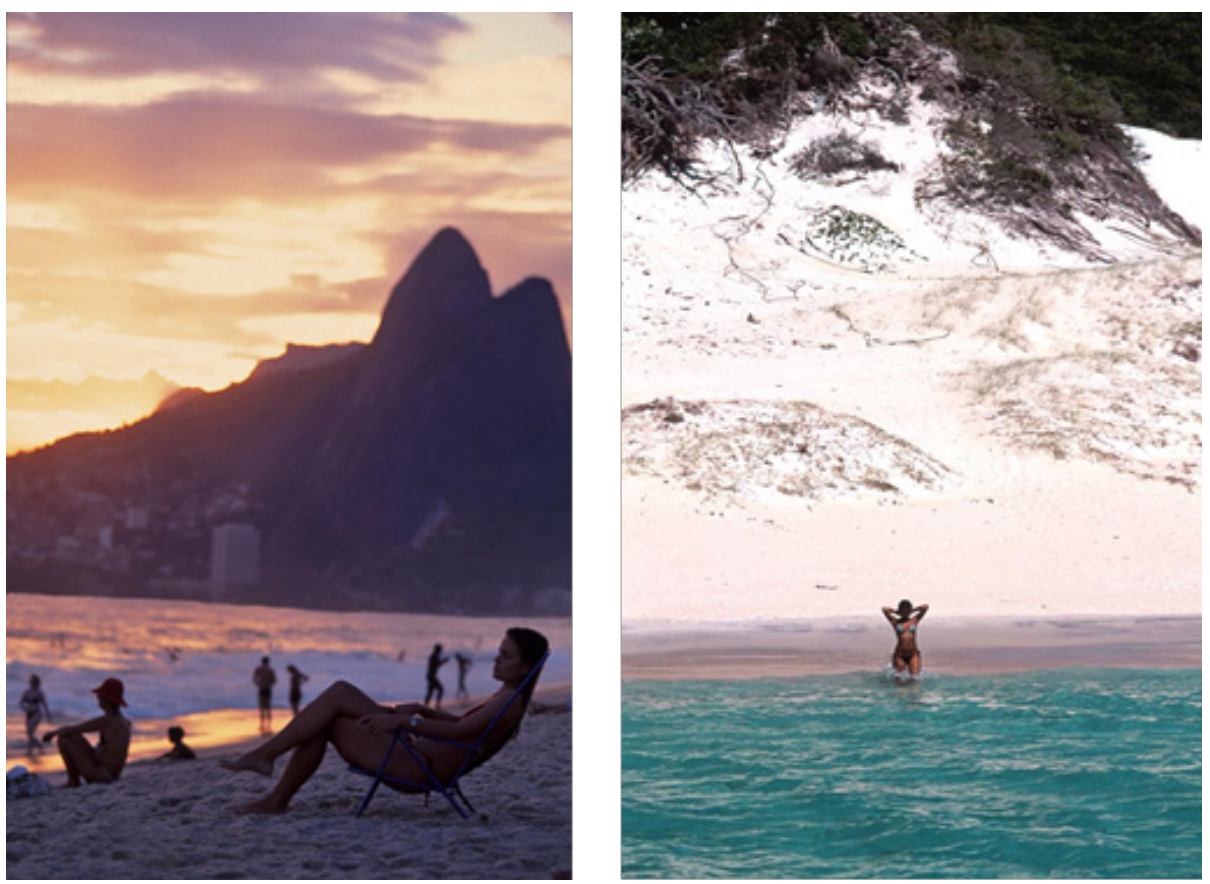

Figures 11 and 12: Miguel Valle de Figueiredo, A Girl from Ipanema (2008); Mermaid (2007) Source: https://www.flickr.com/photos/miguelvf/albums/72157603760063735

By saying that he can not "establish what is Brazilian, while object of portraiture," the photographer claims that such affirmation "is not the same thing to say that" he couldn't "photograph the many Brazilians, as 'the' Brazilian." He refers also to the various types that exists in Brazil, because there is no way to translate "two hundred million people with so much variety" and concludes: "The racial logic in Brazil is very difficult to map photographically".

Miguel Valle registers, whose photographic propositions relate to the advertising look, search to induce consumption by offering consumers an experience under an aesthetic world of "artist capitalism"7 (Lipovetsky \& Serroy, 2015, p. 62). As much as one can realize that there is a diversity of identities in Brazil, it is hidden there also the situation of merchandise that culture and subject identities appear to strengthen stereotypes, such as the "Brazilian woman" sold as attractive packages tour around the world.

His choice is not objectively proposing an identity or to define who is the "Brazilian woman", but to present a stereotypical identity of her, a woman with accessible manners and connected to the myths that are part of the history of Brazil.

\section{FinAL CONSIDERATIONS}

According Marilena Chauí (1995, p. 34) the act of staring is an activity since the act of looking is developed by and depends on each individual experience, but it is also exercised in a passivity anchored in discourse structures that engender the world. Such

\footnotetext{
7 The artist capitalism not only developed a proliferating supply of aesthetic products, as created a craving for news consumers, animations, shows, tourist evasions, emotional experiences, sensitive fruitions: in other words, an aesthetic consumer is more accurately trans-aesthetical (Lipovetsky \& Serroy, 2015, p. 62).
} 
passive behavior can be related to the consumption of new imagery forms of what we can call as a contemporary colonial aesthetics, in whose discourses and images are articulated, spread and disseminated by current media outlets. These outlets both elect the standardization imposed by generalizing systems, as they can also involve and formalize the understanding of a particular culture and about individuals of this same culture.

The construction process of women's visual image reveals discourses supported by perceptions and experiences, but it is also supported by the attribution of generalizing values about their race and gender inferiority. So, to speak about a contemporary Brazilian woman is also to talk about issues of race and colonial view that overlaps the gender issue.

Based on this assessment, it is stated that André Cepeda and Miguel Valle de Figueiredo revealed generalizing discourses of Brazil. Figueiredo, who was more than 30 times to the country, portrayed in a fully commercial way both lands and Brazilian people. His interest is founded on a purely commercial basis to represent picturesque images accompanied the female body. In his pictures, he exposes women as part of nature, such as exotic animal, and, unconsciously or not, also favor a sex trade through the images.

For his part, Cepeda goes back to a way of cataloging female types. The choice of female nudes, according to the author, refers to the question of classical art of women representation and in his refusal to photograph people of the same sex. If the artistic aesthetic is an extension of the artist himself (Ferry, 2003), the work of carte de visite made by the photographer reveals his general reflection on Brazil. When using the artifice of pose and models, the author represents Brazilian woman without regard to the historical and cultural context that interferes with the understanding of a current Brazilian woman. This form of representation without judgement or reflection, ends by making us believe that the world constructed by the author in his work repeats old concepts to represent the "Brazilian" woman. After all, if the body is political, when having a neutral posture in situations of injustice, one takes the risk of representing the oppressive side.

It is concluded that the peculiarities of the current understanding of the image of Brazilian woman's body, specifically the one formed the Portuguese gaze in the analyzed images, shows multiple layers of new colonizing processes in which Brazilian woman visual image is associated as much sensuality as sexual disposition, filled with the understanding of a colonial body that still persists in the contemporary imagination and stands as a stain in the Brazilian woman's image.

Translated by Lorena Travassos e Priscila Vilarinho

\section{Bibliographic References}

Alves, J. F (2004). O "brasileiro" oitocentista - representações de um tipo social. In B. Vieira (Ed.), Grupos sociais e estratificação social em Portugal no Século XIX (pp. 193-199). Lisbon: ISCTE. 
Baptista, M. M. (2013). A Identidade cultural Portuguesa: do colonialismo ao pós-colonialismo: memórias sociais, imagens e representações identitárias. Comunicação e Sociedade, 24, $270-287$.

Barradas, C. (2009). Poder ver, poder saber. A fotografia nos meandros do colonialismo e pós-colonialismo. Revista Arquivos da memória: Antropologia, Arte e Imagem, 5-6, 59-79.

Barthes, R. (1984). A câmara clara. Rio de Janeiro: Nova Fronteira.

Berger, J. (1972). Ways of seeing. London: Penguin Books.

Butler, J. (1997). Problemas de gênero: feminismo e subversão da identidade. Porto Alegre: Tomo Editorial/ Palmarinca.

Cepeda, A. (2014). Rua Stan Getz. Lisbon: Pierre Von Kleist Editions.

Chauí, M. (1995). Janela da alma, espelho do mundo. In A. Novaes (Ed.), O olhar (pp. 31-63). São Paulo: Cia das Letras.

Cotton, C. (2013). A fotografia como arte contemporânea. São Paulo: Martins Fontes.

Cunha, M. C. (1987). Olhar Escravo, Ser Olhado. In M. Lissovsky \& P. Azevedo (Eds.), Escravos brasileiros do século XIX na fotografia de Christiano Jr (pp. xxiii- xxx). São Paulo: Editora Ex Libris.

Edwards, E. (2008). Representação da Mudança: A Construção do Etnográfico na Fotografia do século XIX. Revista Comunicação e Linguagens, 39, 97-118.

Ewing, W. (1996). The body: photoworks of the human body. London: Thames \& Hudson.

Fabris, A. (2004). Identidades visuais: uma leitura do retrato fotográfico. Minas Gerais: Editora UFMG.

Ferry, L. (2003). Homo Aestheticus - a invenção do gosto na era democrática. Coimbra: Almedina.

Freitas, M., (2011). O cotidiano afetivo-sexual no Brasil colônia e suas consequências psicológicas e culturais nos dias de hoje. Ponta de Lança: Revista Eletrônica de História, Memória a Cultura, 5(9), 53-58. Retrieved from http://www.seer.ufs.br/index.php/pontadelanca/article/view/1577/2710

Freud, S. (1974). Fetichismo. In Obras Psicológicas Completas de Sigmund Freud. Edição standard brasileira Vol. XXI (pp. 173-185). Rio de Janeiro: Imago.

Guattari, F. (1992). Caosmose. Um novo paradigma estético. São Paulo: Ed. 34.

Gomes, M. S. (2012). A imagem do Brasil no exterior e o turismo: a operacionalização do Plano Aquarela em Portugal. Rosa dos Ventos, 4(4), 506-521. Retrieved from http://www.ucs.br/etc/revistas/index.php/ rosadosventos/article/view/1494

Gorender, J. (1987). A face escrava da Corte Imperial Brasileira. In M. Lissovsky \& P. C. Azevedo (Eds.), Escravos brasileiros do século XIX na fotografia de Christiano Jr (pp. xxxi-xxxvi). São Paulo: Editora Ex Libris.

Hall, S. (1996). The work of representation. In S. Hall (Ed.), Representation. Cultural representation and cultural signifying practices (pp.13-74). London, Thousand Oaks \& New Delhi: Sage.

Higonnet, A. (1992). Criar, Criações: séculos XIX e XX. In G. Duby \& M. Perrot (Eds.), Imagens da Mulher (pp. 140-173). Porto: Edições Afrontamento.

Hirschfeld, M. (1982). Fetichismo: fonte de amor. In Enciclopédia da educação sexual [Vol. 2], p.199. São Paulo: Iracema. 
Leite, M. (2011). As fotografias cartes de visite e a construção de individualidades. Interin: Revista do programa de Pós- Graduação em Comunicação e Linguagens, 11 (1), 1-16. Retrieved from http://interin.utp.br/index. php/volı/article/viewFile/42/34.

Le Goff, J. (2003). Documento/Monumento. In História e Memória (pp. 525-539). Campinas, São Paulo: Unicamp.

Lipovetsky G. \& Serroy, J. (2015). A estetização do mundo: viver na era do capitalismo artista. São Paulo: Companhia das Letras.

Lissovsky, M. \& Azevedo, P. (1987). O fotógrafo Cristiano Jr. In M. Lissovsky \& P. Azevedo (Eds.), Escravos brasileiros do século XIX na fotografia de Christiano Jr. (pp. ix-xv). São Paulo: Editora Ex Libris.

Mulvey, L. (1975). Visual Pleasure and Narrative Cinema. Screen, 16(3), o6-27.

Mulvey, L. (1989). Afterthoughts on 'Visual Pleasure and Narrative Cinema' inspired by King Vidor's Duel in the Sun (1946). In Visual and Other Pleasures (pp. 29-38). London: The Macmillan Press Ltd.

Mulvey, L. (1996). Fetishism and Curiosity. London: British Film Institute.

Metz, C. (1985). Fotografía y fetiche. Revista Octobre, 34, 123-133.

Naranjo, J. (2006). Fotografía, antropología y colonialismo (1845-2006). Barcelona: Colección FotoGGrafia.

Os segredos da mulher brasileira (2010, August). Focus, 555.

Phelan, P. (1993). Unmarked: The Politics of Performance. London and New York: Routledge.

Pinho, O. (2004). Qual é a identidade do homem negro? Revista Democracia Viva, 22, 64-69.

Pontes, L. (2004). Mulheres brasileiras na mídia portuguesa. Cadernos Pagu, 23, 229-256. Retrieved from http://www.scielo.br/pdf/cpa/n23/n23ao8.pdf

Roberts, A. (1988). Photographs and African history: Review Article. Journal of African History, 29, 301-311. Retrieved from http://www.jstor.org/stable/182386

Said, E. (1978). Orientalismo: O oriente como invenção do Ocidente. São Paulo: Companhia das letras.

Solomon-Godeau, A. (1991). Photography at the dock: essays on photographic history, institutions, and practices. Minneapolis: University of Minnesota Press.

Vanifas, R. (1997). Moralidades brasílicas: deleites sexuais e linguagem erótica na sociedade escravista. In C. F. Cardoso \& R. Vainfas (Eds.), História da vida privada no Brasil (pp. 221-274). São Paulo: Companhia da Letras.

Vicente, F. (Ed.) (2014). O império da visão: fotografia no contexto colonial português (1860-1960). Lisbon: Edições 70.

\section{WEBGRAPHY}

André Cepeda, About André Cepeda. Retrieved from http://www.andrecepeda.com/

André Cepeda, Rua Stan Getz. Retrieved from http://www.andrecepeda.com/projects/rua-stan-getz/. 
André Cepeda, São Paulo em corte, Agnaldo Farias. Retrieved from http://www.andrecepeda.com/projects/ sao-paulo-em-corte/

Miguel Valle de Figueiredo, Flickr Page, Ain't life a beach? Album, Retrieved from https://www.flickr.com/ photos/miguelvf/albums/72157603760063735

Museu Nacional de Arte Contemporânea do Chiado, Programação, Botânica de Vasco Araújo. Retrieved from: http://www.museuartecontemporanea.gov.pt/programs/view/5

Photo Clec Project (Photographs, Colonial Legacy and Museums in Contemporary European Culture), Retrieved from http://photoclec.dmu.ac.uk/

Vasco Araújo, Botânica. Retrieved from http://vascoaraujo.org/Botanica.

\section{Biographical Note}

Lorena Travassos has a master degree in Communication (UFPB - Brazil), PhD student in Communication Sciences at Universidade Nova de Lisboa (FCSH-UNL), Center for Research in Communication, Information and Digital Culture - Polo FCSH/NOVA (CIC.Digital) reseacher, CAPES grantee (Full Doctoral Program), Brazil.

E-mail: lorenakrs@gmail.com

Rua Diogo do Couto, 27, 1D, Lisbon, 1100-195, Portugal

* Submitted: 24-07-2017

* Accepted: 09-11-2017 